\title{
The Devil is in the Details: Community Based Participatory Research
}

\author{
Karen Patricia Williams
}

Published online: 11 February 2012

(C) Springer Science+Business Media, LLC 2012

Community based participatory research (CBPR) has gained prominence in the last few years, particularly when the National Institutes of Health issued a program announcement in 2006 and established a special emphasis study section. Traditionally foundations like the W.K. Kellogg Foundation were the primary funders for CBPR. The literature is filled with information about the principles of CBPR [1] and/or establishing collaborations with the community [2]. It is not unusual to hear the discourse of oldtimers and newcomers debating the implementation of a CBPR project. However, what is missing in the literature and in the discourse is attention to the administration of CBPR projects.

The administration must be different and those who administer must be mindful of this. The very nature of CBPR elevates the research administration stakes. One of the things that makes community based research a little different from traditional research approaches is the number of entities including stakeholders, both the public and private sectors, influential community based organizations, and academic centers, to name a few, that might all be involved in the research at various points along the continuum. When all the partners are playing by the established rules of engagement, life is grand. Partners affirm that they are not doing research just for research's sake and everyone involved sees and hears how the research is making a difference.

But when intervention fidelity has been breached or the political environment adversely impacts a partner who has a major role in the outcome of the research, what do we do

\footnotetext{
K. P. Williams $(\varangle)$

Obstetrics, Gynecology and Reproductive Biology,

Michigan State University,

626 E. Fee Hall,

East Lansing, MI 48824, USA

e-mail: Karen.Williams@hc.msu.edu
}

then? How do we keep reputations intact among the stakeholders, knowing we do not want to claim our 15 minutes of fame or shame by being "Twittered"?

Because of the various stakeholders, who may have their own agendas and bring their own history with each other to the project, some days we must envy colleagues who just crunch the numbers or play with mice rather than people in communities. Certainly the cost of doing CBPR can be high.

We all understand that even with CBPR, the principal investigator is responsible for the administrative, fiscal, and scientific oversight of the project. He or she has to be accountable to the funding agency, the scientific community, and the community in which the study is conducted, as well as themselves.

Although we can turn to the literature to glean insights from other disciplines about managing research in general, ultimately the answer to managing CBPR research is not academic. It is a matter of the relationships that are forged over time. It is the trust that manifests itself when partners know that there is not going to be a research drive-by, but that each partner is in it for the long haul. It is when the principal investigator gains the trust of the community that in the midst of turf wars and other political wrangling, the partners feel that they have their backs covered when represented at the ivy-covered tower.

The answer to CBPR research administration is not academic but elementary, remembering that the academics are always the outsiders and guests in the partner's house. The fact is that the PIs from the academy have different roles in this type of work. They have to mind their manners, always affording the partners the level of respect given to program officers. The community gatekeepers do not have to let us into their house. We must be sure to pick up after ourselves; we cannot just waltz in for our time on the agenda and waltz right out afterwards, like the "big I and the little you." In fact 
we need to clear our schedules so that we can answer the questions and address the concerns of those who want to have a chat with us after the meeting, allowing us to pick up the hidden agendas left on the table. Surely we must thank the communities. We have to always give thanks for the opportunity to conduct research with them in front of others in the community and among our community of scholars. Finally, we want to leave the community with capacity (skill-)-building gifts. When we continue to practice the type of good manners that our mothers taught us, our partners will seek opportunities to invite us back into their houses. Thus, when difficult administrative decisions need to be made, we need not be envious of our colleagues who crunch numbers and play with mice.

\section{References}

1. Israel BA, Schulz A, Parker EA, Becker AB, Allen AJ, Guzman JR (2008) Critical issues in developing and following CBPR principles. In: Minkler M, Wallerstein N (eds) Community-based participatory research for health: from process to outcomes. Jossey-Bass, San Francisco

2. Nyden P (2003) Academic Incentives for Faculty Participation in Community-based Participatory Research. J Gen Intern Med 18 (7):576-585 